Canadian Science Publishing

Canadian Journal of Earth Sciences Revue canadienne des sciences de la Terre

\title{
Biochemostratigraphy of the Eramosa Formation in southwestern Ontario, Canada
}

\begin{tabular}{|r|l|}
\hline Journal: & Canadian Journal of Earth Sciences \\
\hline Manuscript ID & cjes-2015-0223.R1 \\
\hline Manuscript Type: & Article \\
\hline Date Submitted by the Author: & $11-$ Feb-2016 \\
\hline Complete List of Authors: & $\begin{array}{l}\text { Bancroft, Alyssa M.; The University of Iowa, Department of Earth and } \\
\text { Environmental Sciences } \\
\text { Kleffner, Mark A.; School of Earth Sciences, } \\
\text { Brunton, Frank R.; Ministry of Northern Development, }\end{array}$ \\
\hline Keyword: & $\begin{array}{l}\text { Silurian, Ontario, Eramosa Formation, conodonts, carbonate carbon } \\
\text { isotopes }\end{array}$ \\
\hline &
\end{tabular}

SCHOLARONE ${ }^{m}$

Manuscripts 


\section{Biochemostratigraphy of the Eramosa Formation in southwestern Ontario, Canada}

2

3 Corresponding Author:

4 Alyssa M. Bancroft, Department of Earth and Environmental Sciences, University of lowa, 115 Trowbridge Hall, lowa City, lowa, USA 52242 [alyssa-bancroft@uiowa.edu] $+1(231) 881-0533$

8 9 10

11 Frank R. Brunton, Earth Resources and Geoscience Mapping Section, Ontario Geological Survey,
Willet Green Miller Center, 933 Ramsey Lake Road, Sudbury, Ontario, Canada P3E6B5

[frank.brunton@ontario.ca]

0

1

Mark A. Kleffner, School of Earth Sciences, The Ohio State University Lima, 4240 Campus Drive, Lima, Ohio, USA 45804

[kleffner.1@osu.edu] 
Abstract

The lithostratigraphic term 'Eramosa' was introduced in Ontario more than a century ago to include a distinctive package of thin-to-medium bedded, black-to-medium-brown dolostones that make up key cuesta faces and railway road cuts along the Eramosa River in the City of Guelph, southwestern Ontario, Canada. This stratigraphic unit makes up part of a stacked carbonate succession that constitutes one of the most economically significant Paleozoic sedimentary rocks in Ontario. The strata assigned to the Eramosa have a complex history of lithostratigraphic study and the relative age, regional lithostratigraphic relationships,

32 and varied depositional environments of the Eramosa were poorly understood. This research, 33 which combines conodont biostratigraphy and carbonate carbon $\left(\delta^{13} \mathrm{C}_{\text {carb }}\right)$ isotope stratigraphy to generate a detailed chronostratigraphic framework for the Eramosa Formation in southwestern Ontario, is part of a regional-scale surface and subsurface mapping initiative of the Silurian strata by the Ontario Geological Survey. Dolostone samples from Wiarton and the

37 City of Guelph, Ontario yielded three biostratigraphically important conodonts: Ozarkodina sagitta rhenana, Kockelella walliseri, and Kockelella ortus ortus. The carbonate carbon $\left(\delta^{13} \mathrm{C}_{\mathrm{carb}}\right)$

39 isotope data from the studied intervals record the descending limb of the Sheinwoodian

40 (Ireviken) positive $\delta^{13} \mathrm{C}_{\text {carb }}$ isotope excursion, including a distinctive positive shift in $\delta^{13} \mathrm{C}_{\text {carb }}$

41 isotope values typical of records of the descending limb of the excursion in Laurentia and

42 Baltica. Aldridgeodus minimus was also recovered from these conodont faunas and co-occurrs 43 with Kockelella walliseri, below the last occurrence of Ozarkodina sagitta rhenana (Lower 
44 Kockelella walliseri Zone), suggesting that the range of Aldridgeodus minimus should be

45 extended lower into the Sheinwoodian Stage.

46

47 Keywords: Silurian, Ontario, Eramosa Formation, conodonts, carbonate carbon isotopes

Introduction

50

The Niagaran Provincial Series in the Niagara region of western New York has been

52 studied for 150 years (Berry and Boucot 1970; Brett et al. 1995; Cramer et al. 2011a, 2011b)

53 and recent work in this region (Brett et al. 1995; Cramer et al. 2006; McLaughlin et al. 2008;

54 Cramer et al. 2011a) has provided revisions to the relative age assessment of the Niagaran

55 Provincial Series. Chronostratigraphic control for the Silurian strata in Ontario, Canada is less

56 well-constrained due to a history of limited biostratigraphic and chemostratigraphic studies and

57 the complexities of facies changes from the Appalachian Basin across the Algonquin Arch and

58 into the Michigan Basin (see Brunton 2009; Brunton and Brintnell 2011; and Brunton et al.

59 2012). This is further complicated by lithostratigraphic nomenclatural differences across the

60 Niagara River between the United States Geological Survey (USGS) and the Ontario Geological

61 Survey (OGS) (Brett et al. 1995; Brunton et al. 2005; Cramer et al. 2011a). Study of the strata in

62 southwestern Ontario, Canada is critical for understanding the tectonostratigraphic

63 relationships between the foreland Appalachian Basin and the intracratonic Michigan Basin

64 during the Silurian Period. 
Due to refined processing techniques (Jeppsson et al. 1985; Jeppsson 1987; Jeppsson and Anehus 1995, 1999) and an increase in the number of studied sections globally, Silurian conodont taxonomy and biostratigraphy (specifically of the Llandovery Stage and Wenlock Series) have undergone significant revisions in the last two decades (e.g. Jeppsson 1997; Jeppsson et al. 2006; Männik 1998, 2007a, 2007b). As a result, the resolution of Silurian conodont biozonation has increased by an order of magnitude and acted as a catalyst for a revolution in the study of biogeochemical events. A series of extinction events during the Silurian Period (e.g. Jaeger 1959; Jeppsson 1990, 1998; Jeppsson and Aldridge 2000; Jeppsson et al. 1995, 2006; Cramer et al. 2010a, 2010b; Cramer et al. 2012) are correlative with perturbations in the global carbon cycle, which are recorded as major positive carbonate carbon $\left(\delta^{13} \mathrm{C}_{\text {carb }}\right)$ isotope excursions in marine carbonates. These combined biological and chemical events provide useful chronostratigraphic markers for high-resolution global correlation of Silurian strata, particularly when biostratigraphic information is limited. As a result, integrated conodont biostratigraphy and carbonate carbon $\left(\delta^{13} C_{c a r b}\right)$ isotope chemostratigraphy for the Silurian System now provide a high-resolution chronostratigraphic framework for Silurian strata globally (Cramer et al. 2011a).

Herein, two outcrops from Wiarton on the central Bruce Peninsula (Highway 6 roadcut and Ledgerock Quarry) and two cores from the City of Guelph (MW 04-06 and MW 07-06) were sampled for conodont biostratigraphy and carbonate carbon $\left(\delta^{13} \mathrm{C}_{\text {carb }}\right)$ isotope chemostratigraphy. The chronostratigraphic framework constructed from these data not only permits a more accurate age determination and regional correlation for the Eramosa Formation in southwestern Ontario but also permits correlation to the Niagaran Provincial Series in New 
87 York. This research is also a part of the Ontario Geological Survey's multi-year, regional-scale study to constrain the bedrock aquifers and karst of the Niagara Escarpment.

\section{Stratigraphic Nomenclature}

Although the first comprehensive report of the Silurian System of Ontario was published by Logan in 1863, the relative ages, stratigraphic relationships, and depositional environments of these lithostratigraphic units are only now being addressed in a systematic manner (Brunton and DeKeyser 2004; Brunton 2009; Armstrong and Carter 2010; Brunton and Brintnell 2011;

97 for a cuesta-forming dolostone succession in the City of Guelph along the Guelph Line railway cut on the west side of the Eramosa River. Since its designation as a lithostratigraphic unit, the strata encompassing the Eramosa has been given formational rank (Nowlan 1935; Shaw 1937;

Rickard 1975; Brett et al. 1995; Brunton 2009; Brunton and Brintnell 2011; Brunton et al. 2012); been referred to as the uppermost member of the Lockport Formation and Amabel Formation (Williams 1919; Caley 1940; Bolton 1953; Liberty and Bolton 1971); and been assigned as the basal member of the Guelph Formation (Sanford 1969; Armstrong and Meadows 1988; Johnson et al. 1992; Armstrong and Dubord 1992; Armstrong 1993a, 1993b; Armstrong and Carter 2006; Armstrong and Dodge 2007). The Ontario Geological Survey (OGS) is in the process of completing a multi-year study mapping the bedrock aquifers and karst of the Niagara

107 Escarpment in southwestern Ontario (Brunton 2009; Brunton and Brintnell 2011; Brunton et al. 2012). This work by the OGS has retained the formational designation of the Eramosa and has 
109 resulted in the recognition of three members of the Eramosa Formation, in ascending order:

110 Vinemount, Reformatory Quarry, and Stone Road (Brunton 2009; Brunton and Brintnell 2011;

111 Brunton et al. 2012). The Reformatory Quarry (less than 0.5 km from Williams' 1919 section, on

112 the east side of the Eramosa River) in the City of Guelph has been described and named as the

113 type section of the Eramosa Formation in southwestern Ontario (Brunton 2009; Brunton and

114 Brintnell 2011; Brunton et al. 2012).

115 The age of the Eramosa Formation in southwestern Ontario is also an issue of debate.

116 There were no biostratigraphic studies of this lithostratigraphic unit until recently, when Stott

117 et al. (2001) utilized conodonts to assign the Eramosa strata at the Highway 6 roadcut in

118 Wiarton, Ontario to the Sheinwoodian Ozarkodina sagitta rhenana Superzone (see Fig. 2). The

119 presence of a morphotype of Ozarkodina sagitta rhenana characteristic of the Lower Kockelella

120 walliseri Zone (middle Sheinwoodian) further restricted their age diagnosis of the Eramosa

121 strata at this locality (Stott et al. 2001). This study combines conodont biostratigraphy and

122 carbonate carbon $\left(\delta^{13} \mathrm{C}_{\text {carb }}\right)$ isotope stratigraphy to generate a more detailed

123 chronostratigraphic framework for the Eramosa Formation in southwestern Ontario.

125 Geological Setting

The province of Ontario, Canada was located on the northeastern margin of the

128 paleocontinent Laurentia, south of the equator in the subtropical climate belt, during the

129 Silurian Period (Cocks and Torsvik 2002). The Algonquin Arch (Fig. 1) acted as a structural

130 barrier (intermittently active forebulge region during the Silurian, Brunton et al. 2012) between 
131 the Michigan Basin and the foreland Appalachian Basin and restricted the influx of siliciclastics

132 to the carbonate-and-evaporite-dominated Michigan Basin (Johnson et al. 1992). Wiarton,

133 Ontario was located to the northwest of the migrating forebulge (Algonquin Arch) and the City

134 of Guelph, Ontario was located to the north of this forebulge (Fig. 1).

Abrupt temporal and spatial changes in depositional environments between the

Laurentian cratonic area (Michigan Basin) and the foreland Appalachian Basin are evident in the

137 significant regional variability in fossil content and sedimentary structures of the Eramosa

138 Formation in southwestern Ontario (Brunton 2009; Brunton and Brintnell 2011; Brunton et al.

139 2012). The Eramosa Formation is interpreted to have been deposited on a broad carbonate

140 ramp that dipped towards the foreland Appalachian Basin. The basal Vinemount Member

141 represents deposition during a short-lived tectonic re-adjustment in the foreland basin that

142 resulted in pulses of terrigenous clay-bearing, dark-brown-to-black dolostones on the the

143 Laurentian cratonic ramp. The overlying Reformatory Quarry Member displays sedimentary

144 features and faunas that indicate deposition from more open marine and higher energy settings

145 (small reef mounds and hummocky and swaley cross-stratification) adjacent to the foreland

146 basin to more restricted marine lagoon-to-estuarine environments with sabkha-like cycles in

147 more cratonic areas. The Reformatory Quarry Member also possess seismites that extend from

148 the Bruce Peninsula in Ontario to the Niagara region in western New York (Brunton 2009;

149 Brunton and Brintnell 2011; Brunton et al. 2012).

150

151

152 


\section{Sample Localities and Methods}

154

155

156

157

158

159

160

161

162

163

164

165

166

167

168

169

170

171

172

173

174

The Eramosa Formation in southwestern Ontario was sampled for both conodont

biostratigraphy and for carbonate carbon $\left(\delta^{13} \mathrm{C}_{\text {carb }}\right)$ isotope stratigraphy at two outcrop

localities in Wiarton (Highway 6 roadcut and Ledgerock Quarry) and two cores (MW 04-06 and

MW 07-06) from the City of Guelph. The lithology of the Eramosa Formation in southwestern

Ontario is predominantly dolostone. Conodont samples from the two localities in Wiarton were digested using unbuffered acetic acid. Due to low yields from the outcrop samples from

Wiarton, the two cores from the City of Guelph were processed utilizing the buffered formic acid technique for conodont extraction (Jeppsson et al. 1985; Jeppsson and Anehus 1995). All

conodont samples have been reposited at the School of Earth Sciences Orton Geological

Museum at The Ohio State University. The MW 04-06 and MW 07-06 cores were drilled for the

City of Guelph Groundwater Resources Assessment Project and are stored at the Ontario

Geological Survey, Sudbury, Ontario, Canada.

Carbonate carbon $\left(\delta^{13} \mathrm{C}_{\text {carb }}\right)$ isotope samples were analyzed at the Texas Tech University

Stable Isotope Laboratory (Tables 1, 2, 3, 4). Samples were micro-drilled, and the dolomitic

powders were heated for thirty minutes at $480^{\circ} \mathrm{C}$ under a stream of hot, $99.99 \%$ purified helium

to remove water and organic material. To dissolve the calcite, samples were reacted with $100 \%$

phosphoric acid at $25.2^{\circ} \mathrm{C}$ for two hours, and the evolved gas was evacuated and discarded.

Samples were then placed overnight in an agitated and enclosed water bath maintained at

$50^{\circ} \mathrm{C}$. Following the method of $\mathrm{McCrea}(1950)$, the evolved $\mathrm{CO}_{2}$ from the dolomitic powder was

extracted and purified. These gas samples were analyzed on a VG SIRA-12 isotope ratio mass 
175 spectrometer equipped with a microinlet system. All values were obtained using an internal 176 standard, TTU-2 calcite, calibrated against the international standard, NBS-19. Results are 177 reported using the conventional notation of Craig (1957), relative to VPDB (\%o).

\section{Results}

Highway 6 Roadcut and Ledgerock Quarry, Wiarton, Ontario

In the present study, only one sample from the Highway 6 roadcut yielded a

biostratigraphically useful conodont, Ozarkodina sagitta rhenana (Walliser 1964), recovered

14.00-14.10 $\mathrm{m}$ above the base of the section within the Goat Island Formation (Figs. 2, 3, 6). No biostratigraphically useful conodonts were recovered from the Eramosa Formation at this locality. Carbonate carbon $\left(\delta^{13} \mathrm{C}_{\text {carb }}\right.$ ) isotope data (Fig. 3; Table 1) record a value of $+4.26 \%$ at the base of the roadcut and the highest value of $+4.54 \%$. $5.00 \mathrm{~m}$ above the base of the section. Above $5.00 \mathrm{~m}$ from the base of the section, $\delta^{13} \mathrm{C}_{\text {carb }}$ values gradually decrease to approximately $+3.00 \%$ at $14.00 \mathrm{~m}$, but increase to $+3.30 \%$ at $15.00 \mathrm{~m}$ and remain at about that value throughout the remainder of the section. The presence of Oz. s. rhenana within the Goat Island

191 Formation is coincident with gradually declining but elevated carbonate carbon $\left(\delta^{13} C_{\text {carb }}\right)$ 192 isotope values (+3.00\%o) throughout the entire stratigraphic succession (Goat Island and Eramosa formations) at the Highway 6 roadcut in Wiarton, Ontario.

Two samples from the Ledgerock Quarry yielded two biostratigraphically useful conodonts, Ozarkodina sagitta rhenana (Walliser 1964) and Kockelella walliseri (Helfrich 1975) 
197 rhenana was also recovered from a sample higher in the section (5.90-6.00 $\mathrm{m}$ above the base of 198 the section), $0.10 \mathrm{~m}$ above the base of the seismite bed which is $5.60-5.90 \mathrm{~m}$ from the base of 199 the section. The recovery of K. walliseri is below the topmost occurrence of Oz. s. rhenana 200 (Figs. 2, 3, 6). The highest carbonate carbon $\left(\delta^{13} C_{\text {carb }}\right)$ isotope value recorded at the quarry is $201+3.29 \%$, which occurs at the base of the section. The values begin a steady decline to 202 approximately $+1.00 \%$ o throughout the remaining $6.40 \mathrm{~m}$ of the section, however, the lowest 203 value recorded, $+0.61 \%$ was from the top of the quarry (Fig. 3; Table 2 ). The presence of both 204 205 isotope values within the Eramosa Formation at the Ledgerock Quarry in Wiarton, Ontario.

MW 04-06 and MW 07-06 Cores, City of Guelph, Ontario and Kockelella walliseri (Helfrich 1975), were recovered from samples within the MW 04-06 core. The first occurrence of Oz. s. rhenana is from a sample 65.67-63.00 feet down core. $K$. walliseri was recovered from a sample 38.83-37.75 feet down core and is below the highest occurrence of Oz. s. rhenana (30.33-29.42 feet down core). Aldridgeodus minimus Jeppsson (in

213 Calner et al. 2008) was also recovered from this core, from a sample taken 38.83-37.75 feet

214 down core, and it co-occurs with K. walliseri, below the last occurrence of Oz. s. rhenana (Figs.

$2152,4,6)$. Carbonate carbon $\left(\delta^{13} C_{\text {carb }}\right)$ isotope values throughout the MW 04-06 core (Fig. 4; Table 2163 ) are consistently elevated, typically greater than $+2.50 \%$. There is a small decrease in $\delta^{13} \mathrm{C}_{\text {carb }}$ 217 values recorded from 69.25-61.85 feet down core where values fall from $+2.81 \%$ in the upper 218 part of the Goat Island Formation to a low of $+1.51 \%$ near the base of the Eramosa Formation. 
219 Within the Eramosa Formation $\delta^{13} C_{c a r b}$ values record a fairly significant positive shift 220 (approximately $1.00 \%$ o to $1.50 \%$ ) and reach a high of $+3.51 \%$ o (26.42 feet down core) near the 221 middle of the seismite (29.83-24.00 feet down core). The ranges of Oz. s. rhenana and $K$. 222 walliseri overlap at a level in the core (38.83-37.75 feet down core) that is within the positive 223 shift in $\delta^{13} \mathrm{C}_{\text {carb }}$ values, below the seismite, within the Eramosa Formation. Three biostratigraphically useful conodonts, Ozarkodina sagitta rhenana (Walliser 225 1964), Kockelella walliseri (Helfrich 1975), and Kockelella ortus ortus (Walliser 1964), were 226 recovered from samples within the MW 07-06 core. K. walliseri was recovered from four 227 samples that ranged from 169.17-151.92 feet down core, and Oz. s. rhenana was recovered 228 above the highest sample yielding $K$. walliseri (148.50-147.58 feet down core). Aldridgeodus 229 minimus Jeppsson (in Calner et al. 2008) was also recovered from this core (from samples that 230 spanned an interval from 172.58-151.92 feet down core) and it co-occurs with $K$. walliseri, 231 below the last occurrence of Oz. s. rhenana (Figs. 2, 5, 6). Kockelella ortus ortus was recovered 232 from two samples 136.58-136.00 feet and 135.08-133.42 feet, respectively (both of these 233 samples are above the Eramosa seismite, which is located 140.00-137.00 feet down core). 234 Carbonate carbon $\left(\delta^{13} C_{\text {carb }}\right)$ isotope values in the MW 07-06 core (Fig. 5; Table 4) are low in the 235 Goat Island Formation at the base of the core $(+1.24 \%$, decreasing to $+0.88 \%$ o). At the base of 236 the Eramosa Formation $\delta^{13} C_{\text {carb }}$ values fluctuate, but increase, recording a fairly significant 237 positive shift (approximately $1.50 \%$ ) that reaches a high of $+3.02 \%$ (155.92 feet down core).

238 After this positive shift, $\delta^{13} \mathrm{C}_{\text {carb }}$ values begin to gradually decrease to the top of the core, 239 through the remainder of the Eramosa and the overlying Guelph formations. The ranges of $\mathrm{Oz}$. 240 s. rhenana and $K$. walliseri do not overlap in the core, however the range of $K$. walliseri is 
241 coincident with the positive shift in $\delta^{13} \mathrm{C}_{\text {carb }}$ values, whereas the only occurrence of Oz.s.

242 rhenana is above the level of the positive shift in $\delta^{13} \mathrm{C}_{\text {carb }}$ values. The range of $K . o$. ortus is

243 within the gradual decline in $\delta^{13} \mathrm{C}_{\text {carb }}$ values above the seismite in the core.

\section{Discussion}

Highway 6 Roadcut and Ledgerock Quarry, Wiarton, Ontario

The presence of Ozarkodina sagitta rhenana within the Goat Island Formation at the

249 Highway 6 roadcut is coincident with gradually declining, but elevated, carbonate carbon

$250\left(\delta^{13} \mathrm{C}_{\text {carb }}\right)$ isotope values throughout the entire section (Goat Island and Eramosa formations)

251 indicating that these stratigraphic units are within the Ozarkodina sagitta rhenana Superzone

252 and record either the end of the peak or the onset of the descending limb of the Sheinwoodian

253 (Ireviken) positive carbon $\left(\delta^{13} \mathrm{C}_{\text {carb }}\right)$ isotope excursion (Fig. 3; Table 1). The recovery of

254 Kockelella walliseri below the highest occurrence of Ozarkodina sagitta rhenana at Ledgerock

255 Quarry is coincident with steadily decreasing carbonate carbon $\left(\delta^{13} C_{\text {carb }}\right)$ isotope values

256 indicating that this interval of Eramosa strata at this locality is within the Lower Kockelella

257 walliseri Zone of the Ozarkodina sagitta rhenana Superzone and records the descending limb of

258 the Sheinwoodian (Ireviken) positive carbon $\left(\delta^{13} C_{c a r b}\right)$ isotope excursion (Fig. 3; Table 2). The

259 conodont biostratigraphy and carbonate carbon $\left(\delta^{13} \mathrm{C}_{\text {carb }}\right)$ isotope stratigraphy permit one of

260 two conclusions regarding the chronostratigraphic position of the Eramosa at the two localities

261 studied in Wiarton, Ontario. The Eramosa strata exposed at the top of the Highway 6 roadcut

262 correlate to a position either just below or equivalent to the Eramosa strata exposed at the 
263 base of the Ledgerock Quarry (Fig. 3). Both sections are within the Ozarkodina sagitta rhenana

264 Superzone and contain elevated $\delta^{13} C_{\text {carb }}$ values (Fig. 3; Tables 1, 2). However, due to the

265 presence of Kockelella walliseri, carbonate carbon $\left(\delta^{13} \mathrm{C}_{\text {carb }}\right)$ isotope values below $+3.00 \%$, and

266 the seismite, it appears that the Eramosa strata above the base at the Ledgerock Quarry sit

267 stratigraphically above the highest strata exposed at the Highway 6 roadcut.

MW 04-06 and MW 07-06 Cores, City of Guelph, Ontario

The interval of the MW 04-06 core from the single occurrence of Kockelella walliseri to

271 the topmost occurrence of Ozarkodina sagitta rhenana (38.83-29.42 feet) can be placed within

272 the Lower Kockelella walliseri Zone of the Ozarkodina sagitta rhenana Superzone, and the

273 remainder of the core sampled below this interval is within the Ozarkodina sagitta rhenana

274 Superzone (Figs. 2, 4). The interval of core that contains Ozarkodina sagitta rhenana below the

275 sole recovery of Kockelella walliseri could potentially be placed within the Ozarkodina sagitta

276 rhenana Zone, however due to the rarity of Kockelella walliseri in this core (only one $\mathrm{P}_{1}\left(\mathrm{~Pa}_{\mathrm{a}}\right)$

277 element recovered), a placement within the Ozarkodina sagitta rhenana Superzone is more

278 appropriate (Figs. 2, 4). The presence of both Oz. s. rhenana and K. walliseri, combined with

279 the carbonate carbon $\left(\delta^{13} \mathrm{C}_{\mathrm{carb}}\right)$ isotope values within the core indicate that the Eramosa strata

280 within the MW 04-06 core records the descending limb of the Sheinwoodian (Ireviken) positive

281 carbon $\left(\delta^{13} \mathrm{C}_{\text {carb }}\right.$ ) isotope excursion (Fig. 4; Table 3). However, the $\delta^{13} \mathrm{C}_{\text {carb }}$ values in the MW 04-

28206 core record a fairly significant positive shift (approximately $1.00 \%$ o to $1.50 \%$ o) within the

283 Eramosa before beginning to decline near the top of the Eramosa. 
In the MW 07-06 core, Ozarkodina sagitta rhenana was recovered from a sample above

the highest sample that yielded Kockelella walliseri, indicating that this interval of the Eramosa (169.17-147.58 feet) is within the Lower Kockelella walliseri Zone of the Ozarkodina sagitta rhenana Superzone (Figs. 2, 5). The recovery of Kockelella ortus ortus above the seismite in the core indicates that this interval of the Eramosa (136.58-133.42 feet) in the core is within the Kockelella ortus ortus Superzone. Ozarkodina sagitta sagitta (Walliser 1964) was not recovered from the core, suggesting that this interval of the Eramosa within the core could potentially be further constrained to the Kockelella ortus ortus Zone (Figs. 2, 5). The Lower Kockelella walliseri Zone combined with the carbonate carbon $\left(\delta^{13} \mathrm{C}_{\text {carb }}\right)$ isotope values in the Eramosa of the MW 07-06 core indicate that the Eramosa strata (below the seismite) record the descending limb of the Sheinwoodian (Ireviken) positive carbon $\left(\delta^{13} \mathrm{C}_{\text {carb }}\right)$ isotope excursion (Fig. 5; Table 4). However, the $\delta^{13} \mathrm{C}_{\text {carb }}$ values in the MW 07-06 core record a fairly significant positive shift (approximately 1.50\%) within the Eramosa before beginning to decrease throughout the remainder of the Eramosa Formation and the overlying Guelph Formation. The strata above the Eramosa seismite and within the Kockelella ortus ortus Superzone in the core represent a younger package of deposition of the Eramosa Formation than was sampled at any of the other localities included in this study.

The end (descending limb) of the Sheinwoodian (Ireviken) positive carbon $\left(\delta^{13} C_{\text {carb }}\right)$ isotope excursion is restricted to the Lower Kockelella walliseri Zone of the Ozarkodina sagitta rhenana Superzone (Cramer et al. 2010b). In many sections globally there is a distinct positive shift in $\delta^{13} C_{\text {carb }}$ values recorded in the descending limb of the Sheinwoodian (Ireviken) positive carbon $\left(\delta^{13} \mathrm{C}_{\text {carb }}\right.$ ) isotope excursion (e.g. the Ohessare and Ruhnu cores from Baltica, Figs. 7, 8 in 
Cramer et al. 2010b; Route 421 roadcut in Madison, Indiana, Fig. 18 in Brett et al. 2012). The MW 04-06 and MW 07-06 cores from the City of Guelph also record a distinct positive shift in $\delta^{13} C_{\text {carb }}$ values within the descending limb of the Sheinwoodian (Ireviken) $\delta^{13} C_{\text {carb }}$ excursion.

\section{Regional Correlations of the Eramosa}

The strata of the Eramosa Formation of the combined Highway 6 roadcut and Ledgerock Quarry stratigraphic sections of the Wiarton region (Fig. 3) and the Eramosa Formation of the MW 04-06 and MW 07-06 cores of the City of Guelph region (Figs. 4, 5) all record the descending limb of the Sheinwoodian (Ireviken) positive carbon $\left(\delta^{13} C_{\text {carb }}\right)$ isotope excursion within the Ozarkodina sagitta rhenana Superzone, but these sections in southwestern Ontario are not completely correlative.

The occurrence of Kockelella ortus ortus so close to the highest occurrence of Ozarkodina sagitta rhenana is problematic. The highest occurrence of Ozarkodina sagitta rhenana from all sections sampled occurs within the first $10 \mathrm{~cm}$ above the top of the seismite at Ledgerock Quarry in Wiarton (Fig. 3). The lowest sample that contained Kockelella ortus ortus comes from a sample that was between $12.70-17.78 \mathrm{~cm}$ above the top of the seismite in the MW 07-06 core in the City of Guelph (Fig. 5). In the MW 07-06 core, the presence of Kockelella ortus ortus so close to the last occurrence of Ozarkodina sagitta rhenana (136.58-136.00 feet and 148.50-147.58 feet, respectively) in relation to the seismite (these occurrences should be separated by the Upper Kockelella walliseri Superzone - Middle Kockelella walliseri Zone, Kockelella patula Zone, uppermost Kockelella walliseri range - and post Kockelella walliseri interregnum, but are only separated here by a few centimetres, see Fig. 2) suggests one of 
328

329

330

several possibilities: 1 ) there is more than one seismite; 2) the Upper Kockelella walliseri Superzone and post Kockelella walliseri interregnum are represented by a severely condensed interval (a few centimetres at most); 3 ) there is a disconformity that has removed the strata that would represent the Upper Kockelella walliseri Superzone and post Kockelella walliseri interregnum; or 4) the range of Kockelella ortus ortus should be extended down into the middle Sheinwoodian or the range of Ozarkodina sagitta rhenana should be extended up into the latest Sheinwoodian. Using the data from this study, there is insufficient evidence to fully evaluate these hypotheses, however some important observations should be highlighted. The two sections in question (Ledgerock Quarry in Wiarton and the MW 07-06 core in the City of Guelph) are separated by $120 \mathrm{~km}$, and although the Ontario Geological Survey has found no evidence suggesting that there is more than one seismite within the Eramosa lithofacies, the possibility cannot be excluded. No mineralized hardgrounds, phosphatic lags, or other lithologic evidence was observed in the first $20 \mathrm{~cm}$ above the seismite at any of the localities studied herein, therefore it is unlikely that the Upper Kockelella walliseri Superzone and post Kockelella walliseri interregnum are represented by a condensed interval. It is likely that the presence of Kockelella ortus ortus so close to Ozarkodina sagitta rhenana is the result of a disconformity (Brunton 2009; Brunton and Brintnell 2011; Brunton et al. 2012), however at this time there is insufficient evidence to confirm this possibility. In this study, there is no evidence of a co-occurrence of Kockelella ortus ortus with either Kockelella walliseri or Ozarkodina sagitta rhenana, therefore a range extension of either species, based on data herein, is unwarranted (Fig. 2). However, it should be noted that Kockelella patula (Walliser 1964) and Kockelella ortus ortus have been found to co-occur in one sample from Haragan Creek, 
350 Oklahoma (Barrick and Klapper 1976, Table 3, Sample 5) and Kockelella ortus ortus has been 351 recovered below the highest occurrence of Kockelella patula in the Avalanche Lake Sections in 352 the Northwest Territories (Over and Chatterton 1987, Table 4). In two sections in the Carnic 353 Alps, Ozarkodina sagitta rhenana and Ozarkodina sagitta sagitta have been found to co-occur 354 (Corradini and Corriga personal communication 2015). Based on the current known ranges of 355 both subspecies (Kockelella ortus ortus and Ozarkodina sagitta rhenana) it is possible that both 356 species may require range extensions, however more data is required globally before this can 357 be properly demonstrated.

359 Conclusions

The Ontario Geological Survey (Sudbury) has re-evaluated the Silurian stratigraphic

362 succession in southwestern Ontario and the Eramosa Formation within the regional

363 nomenclatural hierarchy (Brunton 2009; Brunton and Brintnell 2011; Brunton et al. 2012). The

364 presence of Ozarkodina sagitta rhenana, Kockelella walliseri, and Kockelella ortus ortus,

365 combined with the carbonate carbon $\left(\delta^{13} C_{\text {carb }}\right.$ ) isotope data (that record the descending limb of

366 the Sheinwoodian (Ireviken) $\delta^{13} C_{\text {carb }}$ excursion), clearly demonstrates that the Eramosa

367 Formation studied herein is limited to an interval from the middle to upper Sheinwoodian Stage

368 (Ozarkodina sagitta rhenana Superzone to Kockelella ortus ortus Zone). The Lower Kockelella

369 walliseri Zone of the Ozarkodina sagitta rhenana Superzone should contain the end of the

370 Sheinwoodian (Ireviken) positive carbon $\left(\delta^{13} \mathrm{C}_{\text {carb }}\right)$ isotope excursion (see Fig. 2; Calner et al. 
371 2004; Cramer et al. 2006; Cramer et al. 2010a, 2010b), and the data herein are consistent with 372 this (Figs. 3, 4, 5). In the Niagara region of western New York the term 'Eramosa' is a designated

374 lithostratigraphic unit given formational rank (Rickard 1975, see discussion in Brett et al. 1995),

375 and the Eramosa in the Niagara region overlies the Goat Island Formation and is, in turn, 376 overlain by the Guelph Formation. The Gasport and Goat Island formations in the Niagara 377 region, are within the Ozarkodina sagitta rhenana Superzone (the Lower Kockelella walliseri 378 Zone of the Ozarkodina sagitta rhenana Superzone occurs within the Goat Island Formation, 379 Cramer et al. 2006, 2010a, 2010b) and the Goat Island Formation records the descending limb 380 of the Sheinwoodian (Ireviken) $\delta^{13} C_{\text {carb }}$ excursion (Cramer et al. 2006; Cramer et al. 2010a, 381 2010b). In the Niagara region the Eramosa Formation is therefore younger than the Lower 382 Kockelella walliseri Zone (possibly either the Upper Kockelella walliseri Superzone or Kockelella 383 ortus ortus Superzone, Cramer et al. 2006, 2010a, 2010b) and above the end of the 384 Sheinwoodian (Ireviken) $\delta^{13} C_{\text {carb }}$ excursion (Cramer et al. 2006, 2010a, 2010b; McLaughlin et al. 385 2008).

In southwestern Ontario, the lower portion of the Eramosa studied herein, is within the

387 Ozarkodina sagitta rhenana Superzone (parts of the Eramosa in the studied sections definitively 388 lie within the Lower Kockelella walliseri Zone, see Figs. 3, 4, 5), and records the descending limb 389 of the Sheinwoodian (Ireviken) $\delta^{13} \mathrm{C}_{\text {carb }}$ excursion. Therefore, the Eramosa Formation in 390 southwestern Ontario correlates to at least some part of the Goat Island Formation (i.e. below 391 the Eramosa Formation) in the Niagara region. The Eramosa Formation in the City of Guelph 392 region correlates with the Vinemount Member of the Goat Island Formation in the Niagara 
393 region (the Ontario Geological Survey considers the Vinemount Member to be the basal 394 member of the Eramosa Formation and not the upper member of the Goat Island Formation; 395 Brunton 2009; Brunton and Brintnell 2011; Brunton et al. 2012). Only the upper portion of the 396 Eramosa Formation (upper Reformatory Quarry Member in the MW 07-6 core from the City of 397 Guelph; Brunton 2009; Brunton and Brintnell 2011; Brunton et al. 2012), above the seismite, 398 studied in southwestern Ontario is possibly correlative with the lower portion of the Eramosa of 399 the Niagara region (Cramer et al. 2006, 2010a, 2010b). Additional work will further clarify 400 interregional chronostratigraphic correlation of the Eramosa Formation and help resolve the 401 lithostratigraphic nomenclatural differences between the United States Geological Survey 402 (USGS) and the Ontario Geological Survey (OGS).

\section{Taxonomic Note}

Aldridge (1985) first reported Ozarkodina? sp. nov. from the Much Wenlock Limestone

407 Formation in Britain, and the species was later named Aldridgeodus minimus by Jeppsson in 408 Calner et al. (2008). The first North American recovery of $A$. minimus was documented by von 409 Bitter and Purnell (2005) from the Eramosa Formation at Hepworth, Ontario. Compared to 410 other Silurian conodont elements, Aldridgeodus minimus is diminutive and, as a result, suffers a 411 higher rate of taphonomic loss, complicating its recovery using standard processing techniques 412 (Calner et al. 2008). Aldridgeodus minimus has been reported to range from the Kockelella 413 ortus ortus Zone through the main part of the Polygnathoides siluricus Zone, late Sheinwoodian 414 through early Ludfordian (Calner et al. 2008; see Fig. 2). In both cores from the City of Guelph, 
415 Ontario, Aldridgeodus minimus (Fig. 6) co-occurs with Kockelella walliseri below the last

416 occurrence of Ozarkodina sagitta rhenana, indicating that the range of Aldridgeodus minimus

417 must be extended down to at least the middle Sheinwoodian Lower Kockelella walliseri Zone

418 (von Bitter et al. 2012; see Fig. 2).

419

420 Acknowledgements

421

422

The authors would like to thank Candace Brintnell (Husky Energy, Calgary, Alberta) for

423 help with the sampling of core; Brad Cramer (University of lowa), and Bill Ausich and Matt

424 Saltzman (The Ohio State University) for their scientific discussions, patience, and help

425 improving this manuscript; and Brian Kemmenoe and Richard Montione at The Ohio State

426 University Campus Microscopy and Imaging Facility for SEM photography. Patrick McLaughlin

427 (Indiana Geological Survey) and Carlo Corradini (University of Cagliari) provided very insightful

428 reviews that significantly helped to improve this manuscript. This work was funded by the NSF

429 Grant \# EAR 0517929 of M.A.K. and the writing of the manuscript was funded by the ACS PRF

430 DNI 53196-DN18 Grant of Brad Cramer (University of lowa). The Ontario Geological Survey

431 provided field support and costs associated with the drilling of cores in the City of Guelph and

432 the processing of chemostratigraphic data. This research represents a contribution to the

433 International Geoscience Programme (IGCP) Project 591.

434

435

436 


\section{References}

Armstrong, D.K. 1993a. Paleozoic geology of the central Bruce Peninsula. Ontario Geological Survey, Open File Report 5856, 19 pp.

Armstrong, D.K. 1993b. Paleozoic geology of southern Bruce Peninsula, southern Ontario. Ontario Geological Survey, Open File Report 5875, 19 pp.

Armstrong, D.K. and Carter, T.R. 2006. An updated guide to the subsurface Paleozoic stratigraphy of southern Ontairo. Ontario Geological Survey, Open File Report 6191, 241 pp.

446

Armstrong, D.K. and Carter, T.R. 2010. The subsurface Paleozoic stratigraphy of southern Ontario. Ontario Geological Survey, Special Volume 7, 301 pp.

Armstrong, D.K. and Dodge, J.E.P. 2007. Paleozoic geology of southern Ontario. Ontario Geological Survey, Miscellaneous Release-Data 219.

Armstrong, D.K. and Dubord, M.P. 1992. Paleozoic geology, northern Bruce Peninsula, southern Ontario. Ontario Geological Survey, Open File Map 198.

Armstrong, D.K. and Meadows, J.R. 1988. Stratigraphy and resource potential of the Eramosa Member (Amabel Formation), Bruce Peninsula, Ontario. Ontario Geological Survey, Open File Report 5662, 89 pp.

Barrick, J.E. and Klapper, G. 1976. Multielement Silurian (late Llandoverian-Wenlockian) conodonts of the Clarita Formation, Arbuckle Mountains, Oklahoma, and phylogeny of Kockelella. Geologica et Palaeontologica, 10: 59-100.

Berry, W.B.N. and Boucot, A.J. 1970. Correlation of the North American Silurian rocks. 
Geological Society of America, Special Paper 102, 289 pp.

460

461

462

463

464

465

466

467

468

469

470

471

472

473

474

475

476

477

478

479

480

Bolton, T.E. 1953. Silurian formations of the Niagara Escarpment in Ontario. Geological Survey of Canada, Paper 53-23, 19 pp.

Branson, E.B. and Mehl, M.G. 1933. Conodont Studies Number 1. The University of Missouri Studies, A Quarterly of Research, VIII(1), $72 \mathrm{pp}$.

Brett, C.E., Goodman, W.M., and LoDuca, S.T. 1990. Sequences, cycles, and basin dynamics in the Silurian of the Appalachian Foreland Basin. In Processes and patterns in epeiric basins. Edited by T. Aigner and R.H. Dott. Sedimentary Geology, 69(3-4): 191-244.

Brett, C.E., Cramer, B.D., Dattilo, B.F., McLaughlin, P.I., Schramm, T.J., and Thomka, J.R. 2012. Middle Paleozoic Sequence Stratigraphy and Paleontology of the Cincinnati Arch: Part 2, northern Kentucky and southeast Indiana. Edited by C.E. Brett, B.D. Cramer, and T.L. Gerke. International Geoscience Programme Project $5912^{\text {nd }}$ Annual Meeting and $1^{\text {st }}$ Foerste Symposium Field Trip Guide.

Brett, C.E., Tepper, D.H., Goodman, W.M., LoDuca, S.T., and Eckert, B.-Y. 1995. Revised stratigraphy and correlation of the Niagaran Provincial Series (Medina, Clinton, and Lockport Groups) in the type area of western New York. United States Geological Survey, Bulletin. Report: B 2086, 66 pp.

Brunton, F.R. 2009. Update of revisions to the early Silurian stratigraphy of the Niagara Escarpment: Integration of sequence stratigraphy, sedimentology, and hydrogeology to delineate hydrogeologic units. In Summary of Field Work and Other Activities 2009, Ontario Geological Survey, Open File Report 6240, pp. 25-1 to 25-20.

Brunton, F.R. and Brintnell, C. 2011. Final update of early Silurian stratigraphy of the Niagara 
481

482

483

484

485

486

487

488

489

490

491

492

493

494

495

496

497

498

499

500

501

Escarpment and correlation with subsurface units across southwestern Ontario and Great Lakes Basin. In Summary of Field Work and Other Activities 2011, Ontario Geological Survey, Open File Report 6270, pp. 30-1 to 30-10.

Brunton, F.R. and DeKeyser, L.-K. 2004. Industrial mineral potential of the Guelph Formation and the Eramosa Member of the Amabel Formation, southwestern Ontario. In Summary of Fieldwork and Other Activities 2004, Ontario Geological Survey, Open File Report 6145, pp. $19-1$ to $19-5$.

Brunton, F.R., DeKeyser, L.-K., and Coniglio, M. 2005. Regional industrial minerals and diagenetic study of the Guelph, Eramosa, and Amabel formations, southwestern Ontario. In Summary of Fieldwork and Other Activities 2005, Ontario Geological Survey, Open File Report 6172, pp. 35-1 to 35-7.

Brunton, F.R., Brintnell, C., Jin, J., and Bancroft A.M. 2012. Stratigraphic architecture of the Lockport Group in Ontario and Michigan - A new interpretation of early Silurian 'basin geometries' and 'Guelph pinnacle reefs'. In $51^{\text {st }}$ Annual Conference - Ontario-New York Oil and Gas Conference, October $23^{\text {rd }}$ to $25^{\text {th }}, 2012$, Niagara Falls, Ontario pp. 1-37.

Caley, J.F. 1940. Paleozoic geology of the Toronto-Hamilton area, Ontario. Geological Survey of Canada, Memoir 224, 284 pp.

Calner, M. and Jeppsson, L. 2003. Carbonate platform evolution and conodont stratigraphy during the middle Silurian Mulde Event, Gotland, Sweden. Geological Magazine, 140(2): 173-203.

Calner, M., Jeppsson, L., and Munnecke, A. 2004. The Silurian of Gotland-Part 1: Review of the 
stratigraphic framework, event stratigraphy, and stable carbon and oxygen isotope development. Erlanger geologische Abhandlungen, Sonderband 5, pp. 113-131.

Calner, M., Eriksson, M.E., Clarkson, E.N.K., and Jeppsson, L. 2008. An atypical intra-platform environment and biota from the Silurian of Gotland, Sweden. GFF (Geologiska Föreningens I Stockholm Förhandlingar), 130(2): 79-86.

Cocks, L.R.M. and Torsvik, T.H. 2002. Earth geography from 500 to 400 million years ago; a faunal and palaeomagnetic review. Journal of the Geological Society of London, 159(6): 631-644.

Corradini, C. 2008. The conodont genus Pseudooneotodus Drygant from the Silurian and Lower Devonian of Sardinia and the Carnic Alps (Italy). Bollettino della Societá Paleontologica Italiana, 46(2-3): 129-148.

Corradini, C. and Serpagli, E. 1999. A Silurian conodont zonation from late Llandovery to end Pridoli in Sardinia. Bollettino della Societá Paleontologica Italiana, 38(2-3): 255-273.

Corriga, M.G., Corradini, C., and Ferretti, A. 2009. Silurian conodonts from Sardinia: An overview. Rendiconti della Societá Paleontologica Italiana, 3(1): 95-107.

Craig, H. 1957. Isotopic standards for carbon and oxygen and correction factors for massspectrometric analysis of carbon dioxide. Geochimica et Cosmochimica Acta, 12(1-2): 133-149.

Cramer, B.D., Saltzman, M.R., and Kleffner, M.A. 2006. Spatial and temporal variability in organic carbon burial during global positive carbon isotope excursions: New insight from high resolution $\delta^{13} C_{\text {carb }}$ stratigraphy from the type area of the Niagaran (Silurian) Provincial Series. Stratigraphy, 2(4): 327-340. 
524 Cramer, B.D., Kleffner, M.A., Brett, C.E., McLaughlin, P.I., Jeppsson, L., Munnecke, A., and

525

526

527

528

529

530

531

532

533

534

535

536

537

538

539

540

541

542

543

544

545
Samtleben, C. 2010a. Paleobiogeography, high-resolution stratigraphy, and the future of Paleozoic biostratigraphy: Fine-scale diachroneity of the Wenlock (Silurian) conodont Kockelella walliseri. Palaeogeography, Palaeoclimatology, Palaeoecology, 294(3): 232241.

Cramer, B.D., Loydell, D.K., Samtleben, C., Munnecke, A., Kaljo, D., Männik, P., Martma, T., Jeppsson, L., Kleffner, M.A., Barrick, J.E., Johnson, C.A., Emsbo, P., Joachimski, M.M., Bickert, T., and Saltzman, M.R. 2010b. Testing the limits of Paleozoic chronostratigraphic correlation via high-resolution (<500 k.y.) integrated conodont, graptolite, and carbon isotope $\left(\delta^{13} \mathrm{C}_{\text {carb }}\right.$ ) biochemostratigraphy across the Llandovery-Wenlock (Silurian) boundary: Is a unified Phanerozoic time scale achievable? Geological Society of America Bulletin, 122(9-10): 1700-1716.

Cramer, B.D., Brett, C.E., Melchin, M.J., Männik, P., Kleffner, M.A., McLaughlin, P.I., Loydell, D.K., Munnecke, A., Jeppsson, L., Corradini, C., Brunton, F.R., and Saltzman, M.R. 2011a. Revised correlation of Silurian Provincial Series of North America with global and regional chronostratigraphic units and $\delta^{13} C_{\text {carb }}$ chemostratigraphy. Lethaia, 44(2): 185202.

Cramer, B.D., Davies, J.R., Ray, D.C., Thomas, A.T., and Cherns, L. 2011b. Siluria revisited: An introduction. In Siluria revisited: A field guide. Edited by D.C. Ray. 2011 International Subcommission on Silurian Stratigraphy Meeting and IGCP 591 Annual Meeting, Ludlow, England, pp. 6-27.

Cramer, B.D., Condon, D.J., Söderlund, U., Marshall, C., Worton, G.J., Thomas, A.T., Calner, M., 
Ray, D.C., Perrier, V., Boomer, I., Patchett, P.J., and Jeppsson, L. 2012. U-Pb (zircon) age constrains on the timing and duration of Wenlock (Silurian) paleocommunity collapse and recovery during the "Big Crisis". Geological Society of America Bulletin, 124(11/12): 1841-1857.

Drygant, D.M. 1974. Simple conodonts of the Silurian and lowermost Devonian of the VolynoPodolian. Paleontologicheskij Sbornik, 10(2): 64-70.

Helfrich, C.T. 1975. Silurian conodonts from Wills Mountain Anticline, Virginia, West Virginia, and Maryland. Geological Society of America Special Paper 161, 82 pp.

Jaeger, H. 1959. Graptolithen und stratigraphie des jungsten Thuringer Silurs. Abhandlungen Akademie Wissenschaften Berlin, Klasse Chemie, Geologie und Biologie 2, 197 pp.

Jeppsson, L. 1987. Some thoughts about future improvements in conodont extraction methods. In Conodonts: Investigative techniques and applications. Edited by R.L. Austin. Ellis Horwood Ltd., Chichester, England, pp. 35, 45-51, 52, 53.

Jeppsson, L. 1990. An oceanic model for lithological and faunal changes tested on the Silurian record. Journal of the Geological Society of London, 147(4): 66-674.

Jeppsson, L. 1997. A new latest Telychian, Sheinwoodian, and early Homerian (early Silurian) standard conodont zonation. Transactions of the Royal Society of Edinburgh: Earth Sciences, 88(2): 91-114.

Jeppsson, L. 1998. Silurian oceanic events: Summary of general characteristics. In Silurian cycles: Linkages of dynamic stratigraphy with atmospheric oceanic, and tectonic changes (James Hall Centennial Volume). Edited by E. Landing, and M.E. Johnson. New York State Museum Bulletin 491, pp. 239-257. 
568 Jeppsson, L. and Aldridge, R.J. 2000. Ludlow (late Silurian) oceanic episodes and events. Journal 569 of the Geological Society, London, 157(6): 1137-1148.

570 Jeppsson, L. and Anehus, R. 1995. A buffered formic acid technique for conodont extraction. $571 \quad$ Journal of Paleontology, 69(4): 790-794.

572 Jeppsson, L. and Anehus, R. 1999. The optimal acetate buffered acetic acid technique for 573 extracting phosphatic fossils. Journal of Paleontology, 73(5): 964-972.

574 Jeppsson, L., Aldridge, R.J., and Dorning, K.J. 1995. Wenlock (Silurian) oceanic episodes and 575 576 events. Journal of the Geological Society, London, 152(3): 487-498.

Jeppsson, L., Eriksson, M.E., and Calner, M. 2006. A latest Landovery to latest Ludlow high-

\section{1} resolution biostratigraphy based on the Silurian of Gotland - A summary. GFF (Geologiska Föreningens I Stockholm Förhandlingar), 28(2): 109-114.

Jeppsson, L., Fredholm, D., and Mattiasson, B. 1985. Acetic acid and phosphatic fossils-A warning. Journal of Paleontology, 59(4): 952-956.

Johnson, M.D., Armstrong, D.K., Sanford, B.V., Telford, P.G., and Rutka, M.A. 1992. Paleozoic and Mesozoic geology of Ontario. In Geology of Ontario. Edited by P.C. Thurston, H.R. Williams, R.H. Sutcliffe, and G.M. Stott. Ontario Geological Survey, Special Volume 4(2), pp. 907-1008.

Liberty, B.A. and Bolton, T.E. 1971. Paleozoic geology of the Bruce Peninsula area, Ontario. Geological Survey of Canada, Memoir 360, 163 pp.

LoDuca, S.T. and Brett, C.E. 1991. Placement of the Wenlockian/Ludlovian boundary in western New York state. Lethaia, 24(3): 255-264.

Logan, W.E. 1863. Geology of Canada. Geological Survey of Canada, Progress Report to 1863, 
983 pp.

591

592

593

594

595

596

597

598

599

600

601

602

603

604

605

606

607

608

609

610

Männik, P. 1998. Evolution and taxonomy of the Silurian conodont Pterospathodus.

Palaeontology, 41(5): 1001-1050.

Männik, P. 2007a. An updated Telychian (late Llandovery, Silurian) conodont zonation based on Baltic faunas. Lethaia, 40(1): 45-60.

Männik, P. 2007b. Recent developments in the upper Ordovician and lower Silurian conodont biostratigraphy in Estonia. Estonian Journal of Earth Sciences, 5(1): 35-46.

McCrea, J. 1950. The isotope chemistry of carbonates and a paleotemperature scale. Journal of Chemical Physics, 18(6): 849-857.

McLaughlin, P.I., Cramer, B.D., Brett, C.E., and Kleffner, M.A. 2008. Silurian high- resolution stratigraphy on the Cincinnati Arch: Progress on recalibrating the layer-cake. In From the Cincinnati Arch to the Illinois Basin: Geological field excursions along the Ohio River Valley. Edited by A.H. Maria and R.C. Counts. Geological Society of America Field Guide 12, pp. $119-180$.

Nicoll, R.S. and Rexroad, C.B. 1968. Stratigraphy and conodont paleontology of the Salamonie Dolomite and Lee Creek Member of the Brassfield Limestone (Silurian) in southeastern Indiana and adjacent Kentucky. Indiana Geological Survey Bulletin 40, 73 pp.

Norford, B.S. 1997. Correlation chart and biostratigraphy of the Silurian rocks of Canada. International Union of Geological Sciences, Publication Number 35, 77 pp.

Nowlan, J.P. 1935. The Silurian stratigraphy of the Niagaran Escarpment in Ontario. Unpublished Thesis, University of Toronto, Toronto, Ontario, Canada. 
611 Over, D.J. and Chatterton, B.D.E. 1987. Silurian conodonts from the southern Mackenzie Mountains, Northwest Territories, Canada. Geologica et Palaeontologica, 21: 1-49.

613 Pander, C.H. 1856. Monographie der fossilen Fische des silurischen systems der Russischbaltischen Gouvernements, von Christian-Heinrich Pander. St-Petersburg: Buchdruckerei der Kaiserlichen Akademie der Wissenschaften.

Rickard, L.V. 1975. Correlation of Silurian and Devonian rocks in New York state. New York State Museum and Science Service Map and Chart Series Number 24, 16 pp.

Sanford, B.V. 1969. Silurian of southwestern Ontario. In Ontario Petroleum Institute, $8^{\text {th }}$ Annual Conference Proceedings, Technical Paper Number 5, pp. 1-44.

620

621

622 623

Shaw, E.W. 1937. The Guelph and Eramosa Formations of the Ontario Peninsula. Transactions of the Royal Canadian Institute, 21(2): 317-362.

Stott, C.A., von Bitter, P.H., Kleffner, M.A., Tetreault, D.K., and Armstrong, D.K. 2001. Evidence for the Wenlockian age of the middle Silurian Eramosa Member, Guelph Formation, southern Bruce Peninsula, Ontario, Canada. In Canadian Paleontology Conference Proceedings Number 11, pp. 50.

von Bitter, P.H. and Purnell, M.A. 2005. An experimental investigation of post-depositional taphonomic bias in conodonts. In conodont biology and phylogeny - Interpreting the fossil record. Edited by M.A. Purnell and P.C.J. Donoghue. Special Papers in Paleontology 73, pp. 39-56.

von Bitter, P.H., Bancroft, A.M., and Purnell, M.A. 2012. The Silurian multielement conodont genus Aldridgeodus Jeppsson in North America. Abstracts with Programs Geological Society of America North-Central Section Meeting, 44(5): 2. 
633 Walliser, O.H. 1964. Conodonten des Silurs. Abhandlungen des Hessischen Landesamtes für

634 Bodenforschung 41, $106 \mathrm{pp}$.

635 Williams, M.Y. 1915a. The middle and upper Siluiran of southwestern Ontario. Geological Survey of Canada, Summary Report 1914, pp. 84-86.

637 Williams, M.Y. 1915b. An eurypterid horizon in the Niagara Formation of Ontario. Geological

638

639

640

641

642

643

644

645

646

647

648

649

650

651

652

653

654

41
Survey of Canada, Museum Bulletin 20, 21 pp.

Williams, M.Y. 1919. The Silurian geology and faunas of Ontario Peninsula and Manitoulin and adjacent islands. Geological Survey of Canada, Memoir 111, 195 pp.

2

3

44

45

46

47

48

49

50

52

53 
655 Figure 1. Present-day map of the Great Lakes Region illustrating the location of Paleozoic

656 structural basins and arches in the region. The localities of Wiarton, Ontario (Highway 6

657 roadcut and Ledgerock Quarry) and the City of Guelph, Ontario (MW 04-06 core and MW 07-06

658 core), and Niagara, New York are shown with shaded circles.

659

660

661

662

663

664

665

666

667

668

669

670

671

672

673

674

675

676 
677 Figure 2. Chronostratigraphy for the upper Telychian Stage of the Llandovery Series and the

678 Sheinwoodian and Homerian stages of the Wenlock Series of the Silurian System.

679 Chronostratigraphy, carbonate carbon $\left(\delta^{13} \mathrm{C}_{\text {carb }}\right)$ isotope excursions, and global conodont

680 zonation from Cramer et al. (2011a); Sardinian conodont zonation from Corradini and Serpagli

681 (1999); Baltic conodont zonation from Männik (2007a, 2007b); selected conodont ranges from

682 Jeppsson (1997), Männik (2007a, 2007b), Corradini (2008), and Corriga et al. (2009). Horizontal

683 bars at the bottom or top of a species range indicate the first appearance datum (FAD) and the

684 last appearance datum (LAD) of that species, respectively. Dashed lines in the range of a

685 species indicate the scattered presence of that species. Ranges of species that extend beyond

686 what is represented in the figure are indicated with an arrow. Numbers between the 'Zone'

687 and 'Subzone' columns under the 'Baltic Conodont Zonation' represent datums of the Ireviken

688 Event and Mulde Event (Jeppsson et al. 2006). Species abbreviations: Pt. - Pterospathodus; Pt.

689 am. - Pterospathodus amorphognathoides; Pt. p. - Pterospathodus pennatus; Oz. p. -

690 Ozarkodina polinclinata; Ps. - Pseudooneotodus; Oz. s. - Ozarkodina sagitta; K. Kockelella; K. o.

691 - Kockelella ortus; A. - Aldridgeodus; Oz. b. - Ozarkodina bohemica; Ct. - Ctenognathodus.

692 Conodont data collected by this study suggests a range extension for Aldridgeodus minimus

693 down to at least the middle Sheinwoodian Lower Kockelella walliseri Zone (please refer to

694 results and discussion sections and Figs. 5 and 6 for conodont occurrence data).

695

696

697

698 
699 Figure 3. Lithostratigraphy, conodont biostratigraphy, and carbonate carbon $\left(\delta^{13} \mathrm{C}_{\text {carb }}\right)$ isotope 700 chemostratigraphy from the Highway 6 roadcut and the Ledgerock Quarry, in Wiarton, Ontario. 701 Potential correlation of the Eramosa strata at the Wiarton localities (uppermost strata exposed 702 at Highway 6 roadcut correlate to a position either just below or equivalent to the strata 703 exposed at the base of the Ledgerock Quarry). All conodont occurrences are noted to the right 704 of the stratigraphic column for the Highway 6 roadcut and to the left of the stratigraphic 705 column for the Ledgerock Quarry. Abbreviations: VPBD - Vienna Pee Dee belemnite; Oz. s. 706 Ozarkodina sagitta; K. - Kockelella; Oz. - Ozarkodina; W. - Wurmiella; Ps. - Pseudooneotodus. 707 708 709 710 711 712 713 714 715 716 717 718 
721 Figure 4. Lithostratigraphy, conodont biostratigraphy, and carbonate carbon $\left(\delta^{13} \mathrm{C}_{\text {carb }}\right)$ isotope 722 chemostratigraphy from the MW 04-06 core, in the City of Guelph, Ontario. All conodont 723 occurrences are noted to the right of the stratigraphic column. Abbreviations: VPBD - Vienna 724 Pee Dee belemnite; Oz. s. - Ozarkodina sagitta; K. - Kockelella; W. - Wurmiella; Oz. 725 Ozarkodina; A. - Aldridgeodus. Note the occurrence of Aldridgeodus minimus below the last 726 occurrence of Ozarkodina sagitta rhenana within the core.

727

728

729

730

731

732

733

734

735

736

737

738

739

740

741 
742 Figure 5. Lithostratigraphy, conodont biostratigraphy, and carbonate carbon $\left(\delta^{13} \mathrm{C}_{\text {carb }}\right)$ isotope 743 chemostratigraphy from the MW 07-06 core, in the City of Guelph, Ontario. All conodont 744 occurrences are noted to the right of the stratigraphic column. Abbreviations: VPBD - Vienna 745 Pee Dee belemnite; Oz. s. - Ozarkodina sagitta; K. - Kockelella; K. o. - Kockelella ortus; W. 746 Wurmiella; A. - Aldridgeodus; Ps. -- Pseudooneotodus. Note the occurrence of Aldridgeodus 747 minimus below the last occurrence of Ozarkodina sagitta rhenana within the core. 748 749 750 751 752 753 754 755 756 757 758 759 760 761 762 
763 Figure 6. Scanning electron microscope (SEM) photomicrographs of conodonts recovered from 764 the Eramosa lithofacies in Wiarton and the City of Guelph, Ontario. 1-3: Ozarkodina sagitta 765 rhenana (Walliser 1964). 1. oral view of $\mathrm{P}_{1}(\mathrm{~Pa})$ element, Ledgerock Quarry, 4.65-4.80 m, 280x;

766 2. oral view of $P_{1}(P a)$ element, Ledgerock Quarry, 5.90-6.00 m, 220x; 3. lateral view of $P_{1}(P a)$ 767 element, MW 07-06 core, 148.67-147.58 feet, 130x. 4-5: Kockelella walliseri (Helfrich 1975). 4. oral view of $\mathrm{P}_{1}(\mathrm{~Pa})$ element, $\mathrm{MW}$ 07-06 core, 169.17-168.17 feet, 71x; 5 . oral view of $\mathrm{P}_{1}(\mathrm{~Pa})$ element, MW 07-06 core, 169.17-168.17 feet, 111x. 6-7: Kockelella ortus ortus (Walliser 1964). 6. lateral view of $P_{1}(\mathrm{~Pa})$ element, $M W 07-06$ core, $135.08-133.42$ feet, $100 x$; 7 . lateral view of $\mathrm{P}_{1}(\mathrm{~Pa})$ element, MW 07-06 core, 136.58-136.00 feet, 297x. 8-13: Aldridgeodus minimus Jeppsson (2003). 8. lateral view of $P_{1}(P a)$ element, $M W$ 07-06 core, 162.42-161.58 feet, 500x; 9. lateral view of $P_{2}(P b)$ element, $M W$ 07-06 core, 166.33-165.50 feet, 240x; 10. lateral view of $\mathrm{S}_{0}(\mathrm{Sa})$ element, MW 07-06 core, 169.17-168.17 feet, 430x; 11. lateral view of $\mathrm{S}_{1}(\mathrm{Sb})$ element, MW 07-06 core, 159.58-158.58, 327x; 12. lateral view of M element, MW 07-06 core, 159.58-158.58 feet, 500x; 13. lateral view of M element, MW 07-06 core, 152.66-151.92 feet, 500x. 14-17: Wurmiella excavata (Branson and Mehl 1933). 14. lateral view of $P_{1}(\mathrm{~Pa})$ element, MW 07-06 core, 179.92 feet, 120 x; 15. lateral view of $P_{1}(P a)$ element, MW 07-06 core, 162.42-161.58 feet, 250x; 16. lateral view of $\mathrm{P}_{1}(\mathrm{~Pa})$ element, $\mathrm{MW}$ 07-06 core, 159.58158.58 feet, 138x; 17. lateral view of $P_{2}(P b)$ element, MW 07-06 core, 179.92 feet, 147x. 18: Kockelella sp. 18. lateral view of $\mathrm{P}_{2}(\mathrm{~Pb})$ ? element, MW 07-06 core, 162.42-161.58 feet, 300x.

19-20: Wurmiella excavata (Branson and Mehl 1933). 19. lateral view of $P_{2}(P b)$ element, $M W$ 07-06 core, 159.58-158.58, 120x; 20. lateral view of $\mathrm{S}_{2}(\mathrm{Sc})$ element, Ledgerock Quarry, 5.906.00 meters, 67x. 21-22: Ozarkodina ex gr. confluens (Branson and Mehl 1933). 21. lateral 
785 view of $\mathrm{P}_{1}(\mathrm{~Pa})$ element, $\mathrm{MW}$ 04-06 core, 43.50-42.50 feet, 170x; 22. lateral view of $\mathrm{S}_{1}(\mathrm{Sb})$

786 element, MW 04-06 core, 23.33-22.67 feet, 127x. 23: “Ozarkodina” sp. 23. lateral view of

$787 \mathrm{P}_{1}(\mathrm{~Pa})$ element, MW 04-06 core, 43.50-42.40 feet, 229x. 24-25: Kockelella? sp. 24. lateral

788 view of $S_{1}(\mathrm{Sb})$ ? element, Ledgerock Quarry, 5.90-6.00 meters, $120 x ; 25$. lateral view of $\mathrm{P}_{2}(\mathrm{~Pb})$

789 element, Ledgerock Quarry, 5.90-6.00 meters, 240x.

790

791

792

793

794

795

796

797

798

799

800

801

802

803

804

805

806 
807 Table 1. Carbonate carbon $\left(\delta^{13} \mathrm{C}_{\text {carb }}\right)$ isotope data with conodont zonation based on recovered 808 conodont biostratigraphic data for the Highway 6 roadcut in Wiarton, Ontario.

809

810 Table 2. Carbonate carbon $\left(\delta^{13} \mathrm{C}_{\text {carb }}\right)$ isotope data with conodont zonation based on recovered 811 conodont biostratigraphic data for the Ledgerock Quarry in Wiarton, Ontario.

812

813 Table 3. Carbonate carbon $\left(\delta^{13} \mathrm{C}_{\text {carb }}\right)$ isotope data with conodont zonation based on recovered 814 conodont biostratigraphic data for the MW 04-06 core in the City of Guelph, Ontario.

816 Table 4. Carbonate carbon $\left(\delta^{13} \mathrm{C}_{\mathrm{carb}}\right)$ isotope data with conodont zonation based on recovered 817 conodont biostratigraphic data for the MW 07-06 core in the City of Guelph, Ontario. 


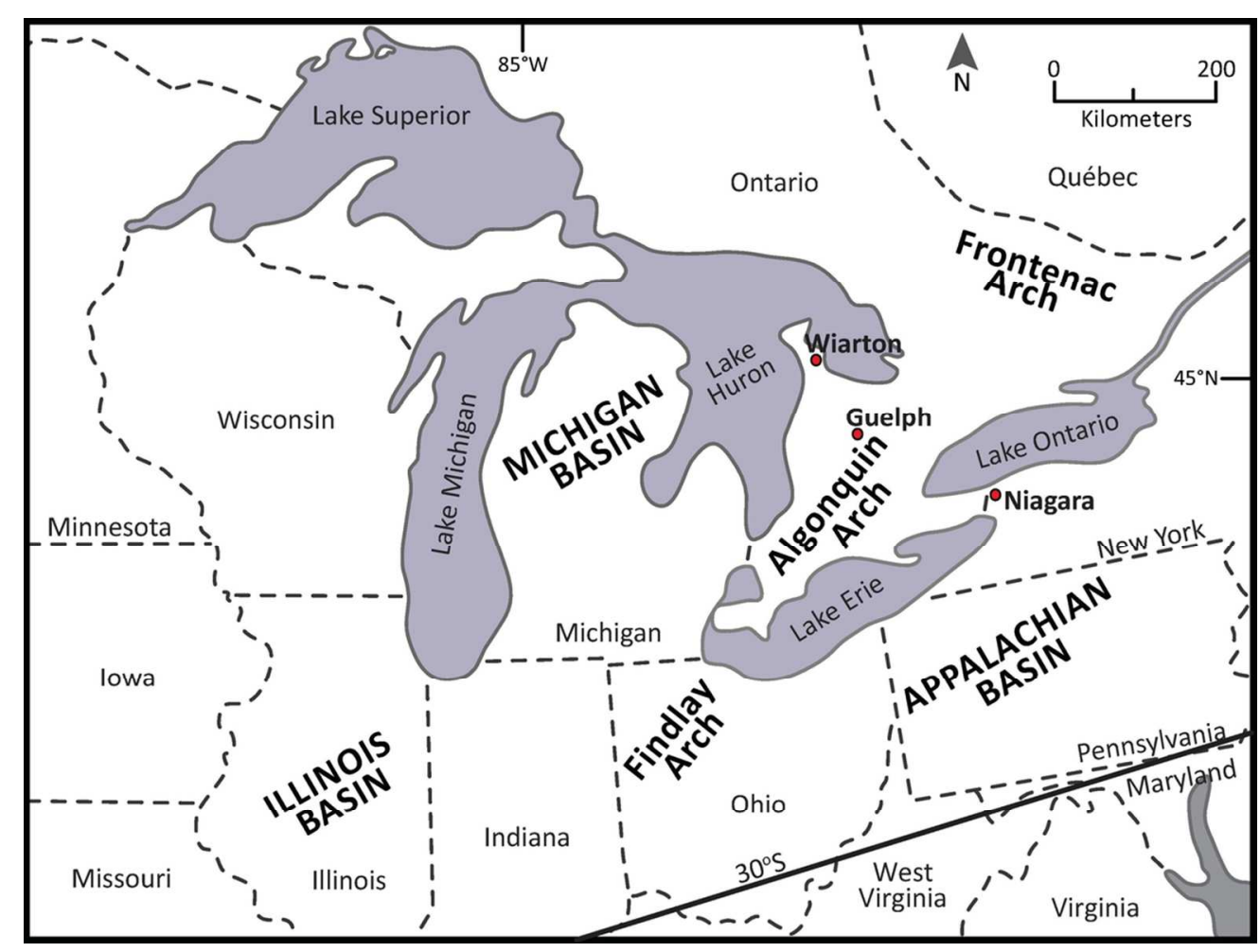

$101 \times 76 \mathrm{~mm}(300 \times 300$ DPI $)$ 


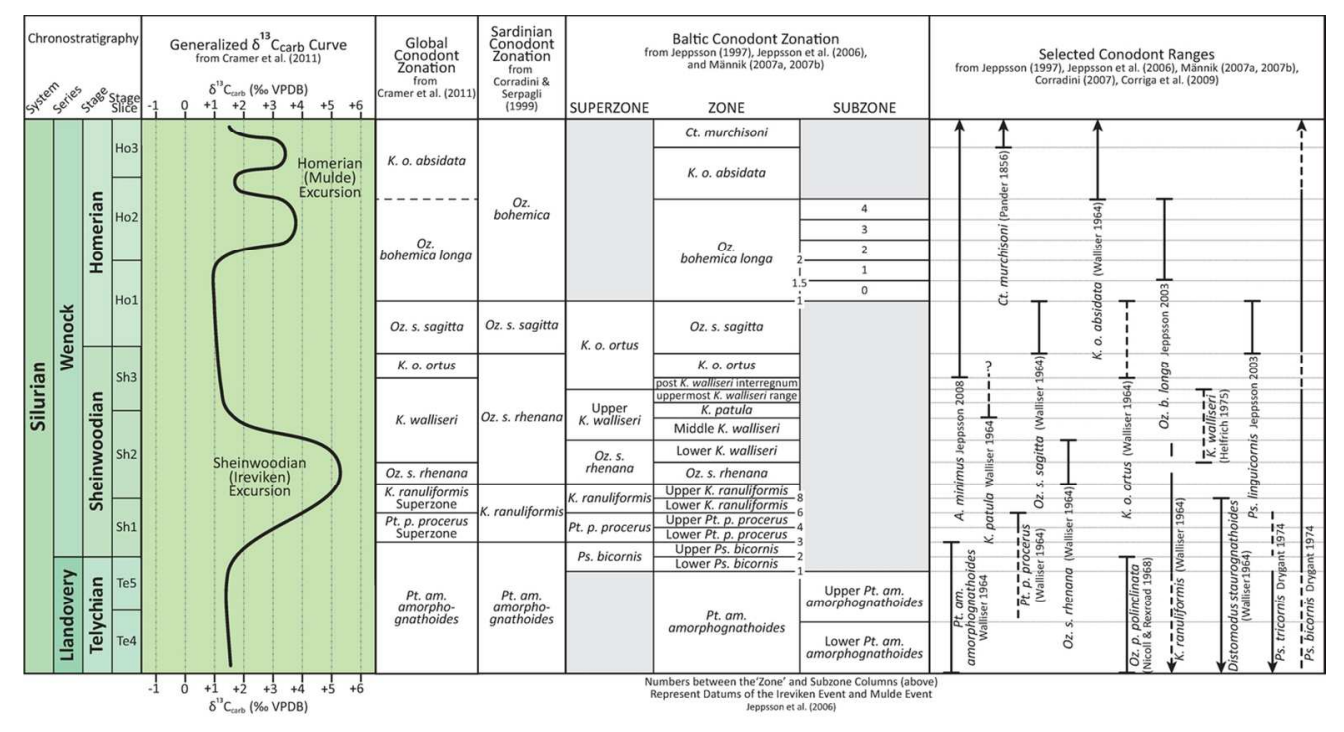

$122 \times 66 \mathrm{~mm}(300 \times 300$ DPI $)$ 


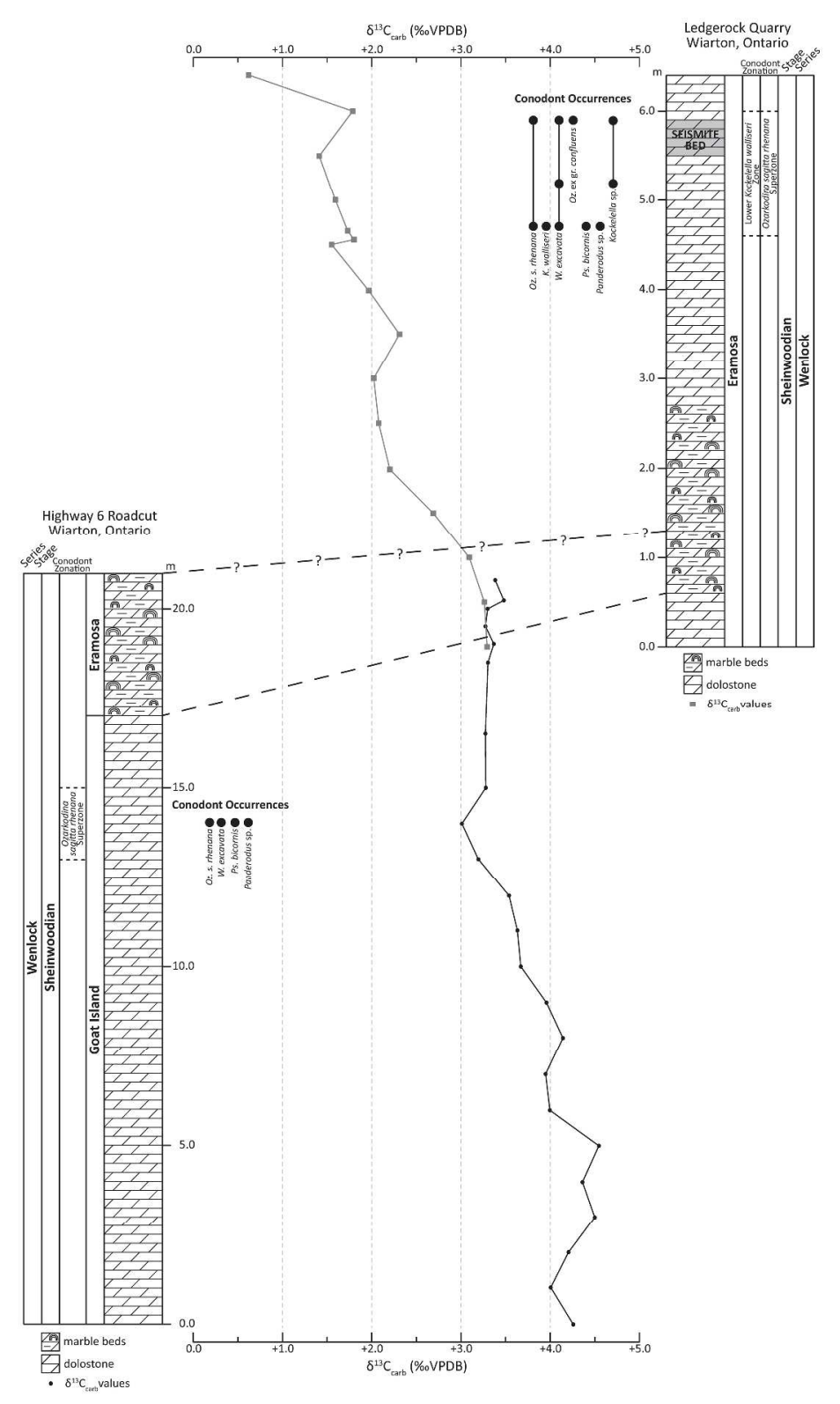

$391 \times 667 \mathrm{~mm}(300 \times 300$ DPI $)$ 


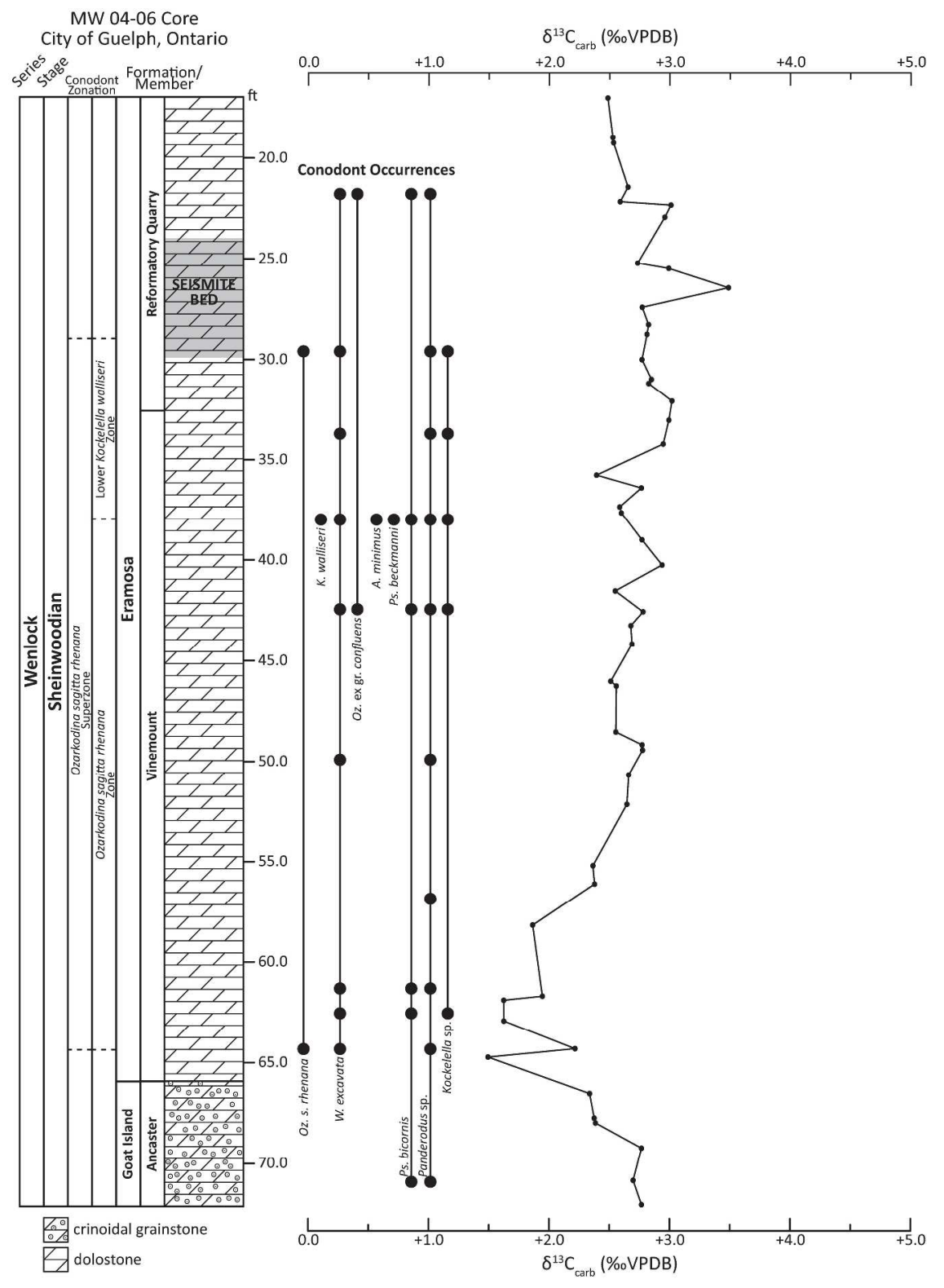

$268 \times 371 \mathrm{~mm}(300 \times 300$ DPI $)$ 


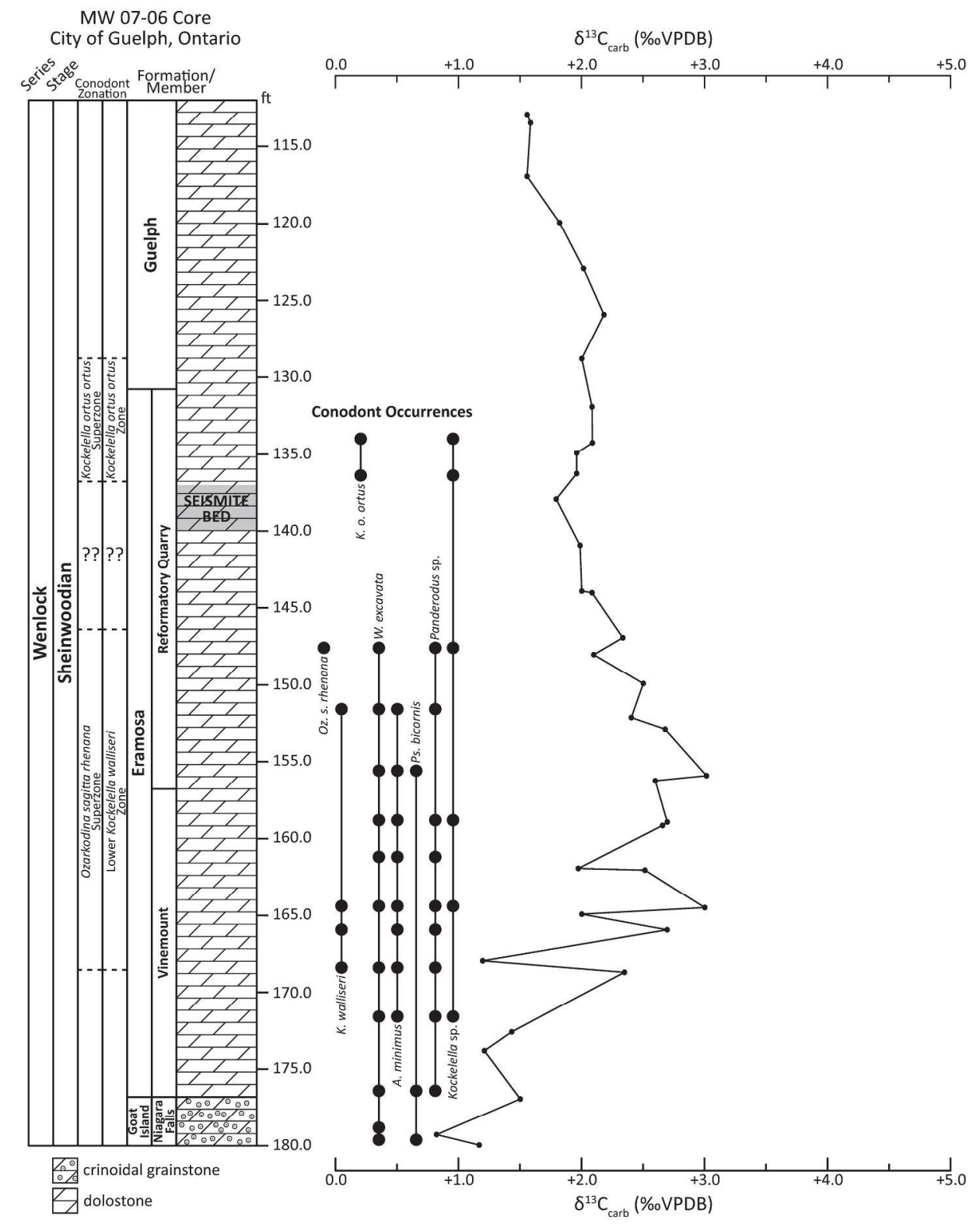

$250 \times 321 \mathrm{~mm}(300 \times 300$ DPI $)$ 


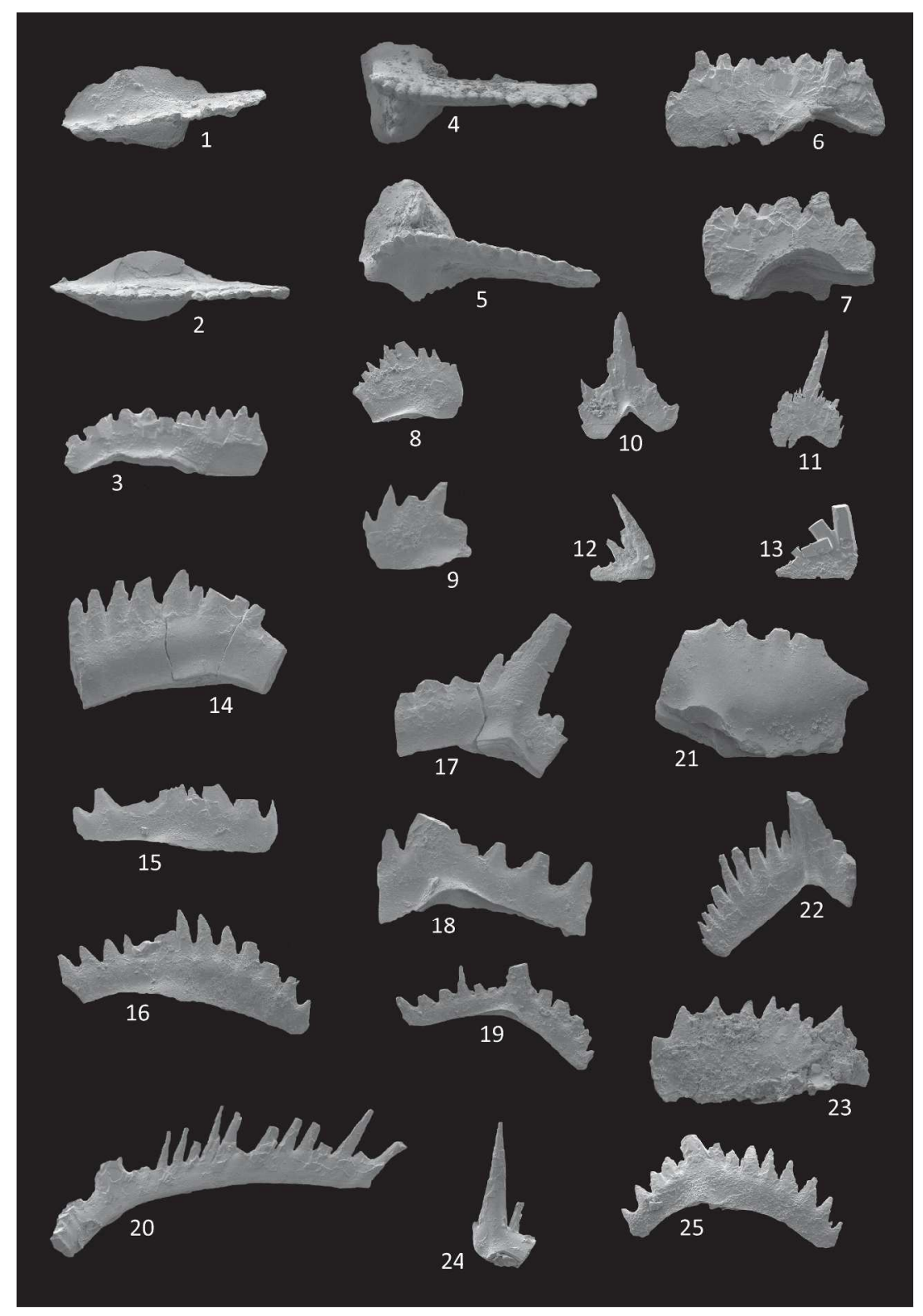

$219 \times 317 \mathrm{~mm}(300 \times 300 \mathrm{DPI})$ 


\begin{tabular}{|c|c|c|c|c|}
\hline \multicolumn{5}{|c|}{ Highway 6 Roadcut Wiarton, Ontairo } \\
\hline Metre & Conodont Zone & $\delta^{13} C_{\text {carb }}$ & $\delta^{18} O$ & Formation \\
\hline 20.80 & Ozarkodina sagitta rhenana Superzone & 3.33 & -6.18 & Eramosa \\
\hline 20.30 & Ozarkodina sagitta rhenana Superzone & 3.42 & -6.36 & Eramosa \\
\hline 20.00 & Ozarkodina sagitta rhenana Superzone & 3.30 & -6.36 & Eramosa \\
\hline 19.50 & Ozarkodina sagitta rhenana Superzone & 3.28 & -6.68 & Eramosa \\
\hline 19.00 & Ozarkodina sagitta rhenana Superzone & 3.42 & -6.38 & Eramosa \\
\hline 18.50 & Ozarkodina sagitta rhenana Superzone & 3.35 & -6.48 & Eramosa \\
\hline 16.50 & Ozarkodina sagitta rhenana Superzone & 3.34 & -6.73 & Goat Island \\
\hline 15.00 & Ozarkodina sagitta rhenana Superzone & 3.34 & -6.80 & Goat Island \\
\hline 14.00 & Ozarkodina sagitta rhenana Superzone & 2.99 & -6.73 & Goat Island \\
\hline 13.00 & ??? & 3.23 & -6.64 & Goat Island \\
\hline 12.00 & ??? & 3.57 & -6.32 & Goat Island \\
\hline 11.00 & ??? & 3.61 & -6.32 & Goat Island \\
\hline 10.00 & ??? & 3.64 & -6.99 & Goat Island \\
\hline 9.00 & ??? & 3.94 & -6.56 & Goat Island \\
\hline 8.00 & ??? & 4.10 & -6.46 & Goat Island \\
\hline 7.00 & ??? & 3.92 & -6.81 & Goat Island \\
\hline 6.00 & ??? & 3.97 & -7.15 & Goat Island \\
\hline 5.00 & ??? & 4.54 & -6.47 & Goat Island \\
\hline 4.00 & ??? & 4.37 & -6.12 & Goat Island \\
\hline 3.00 & ??? & 4.53 & -6.40 & Goat Island \\
\hline 2.00 & ??? & 4.18 & -6.65 & Goat Island \\
\hline 1.00 & ??? & 3.99 & -6.92 & Goat Island \\
\hline 0.00 & ??? & 4.26 & -6.89 & Goat Island \\
\hline
\end{tabular}




\begin{tabular}{|c|c|c|c|c|}
\hline \multicolumn{5}{|c|}{ Ledgerock Quarry Wiarton, Ontairo } \\
\hline Metre & Conodont Zone & $\delta^{13} C_{\text {carb }}$ & $\delta^{18} 0$ & Formation \\
\hline 6.40 & ??? & 0.61 & -4.07 & Eramosa \\
\hline 6.00 & Lower Kockelella walliseri Zone & 1.78 & -5.95 & Eramosa \\
\hline 5.50 & Lower Kockelella walliseri Zone & 1.38 & -6.60 & Eramosa \\
\hline 5.00 & Lower Kockelella walliseri Zone & 1.61 & -6.76 & Eramosa \\
\hline 4.65 & Lower Kockelella walliseri Zone & 1.86 & -6.45 & Eramosa \\
\hline 4.53 & Ozarkodina sagitta rhenana Superzone & 1.79 & -6.58 & Eramosa \\
\hline 4.50 & Ozarkodina sagitta rhenana Superzone & 1.57 & -6.62 & Eramosa \\
\hline 4.00 & Ozarkodina sagitta rhenana Superzone & 1.97 & -6.51 & Eramosa \\
\hline 3.50 & Ozarkodina sagitta rhenana Superzone & 2.31 & -7.18 & Eramosa \\
\hline 3.00 & Ozarkodina sagitta rhenana Superzone & 2.04 & -6.34 & Eramosa \\
\hline 2.50 & Ozarkodina sagitta rhenana Superzone & 2.07 & -6.17 & Eramosa \\
\hline 2.00 & Ozarkodina sagitta rhenana Superzone & 2.20 & -6.41 & Eramosa \\
\hline 1.50 & Ozarkodina sagitta rhenana Superzone & 2.68 & -6.54 & Eramosa \\
\hline 1.00 & Ozarkodina sagitta rhenana Superzone & 3.13 & -6.58 & Eramosa \\
\hline 0.50 & Ozarkodina sagitta rhenana Superzone & 3.28 & -6.88 & Eramosa \\
\hline 0.00 & Ozarkodina sagitta rhenana Superzone & 3.29 & -6.20 & Eramosa \\
\hline
\end{tabular}




\begin{tabular}{|c|c|c|c|c|}
\hline Feet Down Co & Conodont Zone & $\delta^{13} C_{\text {carb }}$ & $\delta^{18} 0$ & Formation \\
\hline 17.00 & ??? & 2.58 & -7.87 & Eramosa \\
\hline 19.00 & ??? & 2.64 & -7.75 & Eramosa \\
\hline 19.25 & ??? & 2.61 & -7.20 & Eramosa \\
\hline 21.42 & ??? & 2.73 & -7.12 & Eramosa \\
\hline 22.25 & ??? & 2.66 & -7.16 & Eramosa \\
\hline 22.42 & ??? & 3.06 & -7.49 & Eramosa \\
\hline 23.00 & ??? & 2.96 & -8.26 & Eramosa \\
\hline 25.25 & ??? & 2.77 & -7.32 & Eramosa \\
\hline 25.42 & ??? & 3.01 & -7.47 & Eramosa \\
\hline 26.42 & ??? & 3.51 & -7.68 & Eramosa \\
\hline 27.42 & ??? & 2.81 & -7.89 & Eramosa \\
\hline 28.25 & ??? & 2.88 & -7.28 & Eramosa \\
\hline 28.75 & ??? & 2.88 & -7.68 & Eramosa \\
\hline 30.00 & Lower Kockelella walliseri Zone & 2.80 & -7.94 & Eramosa \\
\hline 31.08 & Lower Kockelella walliseri Zone & 2.90 & -7.34 & Eramosa \\
\hline 31.25 & Lower Kockelella walliseri Zone & 2.85 & -7.33 & Eramosa \\
\hline 32.08 & Lower Kockelella walliseri Zone & 3.05 & -7.26 & Eramosa \\
\hline 33.08 & Lower Kockelella walliseri Zone & 3.00 & -7.40 & Eramosa \\
\hline 34.25 & Lower Kockelella walliseri Zone & 2.96 & -7.11 & Eramosa \\
\hline 35.83 & Lower Kockelella walliseri Zone & 2.45 & -7.34 & Eramosa \\
\hline 36.33 & Lower Kockelella walliseri Zone & 2.81 & -6.95 & Eramosa \\
\hline 37.25 & Lower Kockelella walliseri Zone & 2.65 & -7.33 & Eramosa \\
\hline 37.75 & Lower Kockelella walliseri Zone & 2.68 & -7.24 & Eramosa \\
\hline 39.00 & Ozarkodina sagitta rhenana Superzone & 2.82 & -7.32 & Eramosa \\
\hline 40.25 & Ozarkodina sagitta rhenana Superzone & 2.94 & -7.42 & Eramosa \\
\hline 41.50 & Ozarkodina sagitta rhenana Superzone & 2.46 & -7.00 & Eramosa \\
\hline 42.42 & Ozarkodina sagitta rhenana Superzone & 2.81 & -7.18 & Eramosa \\
\hline 43.25 & Ozarkodina sagitta rhenana Superzone & 2.75 & -6.96 & Eramosa \\
\hline 44.17 & Ozarkodina sagitta rhenana Superzone & 2.73 & -7.00 & Eramosa \\
\hline 46.08 & Ozarkodina sagitta rhenana Superzone & 2.57 & -7.01 & Eramosa \\
\hline 46.25 & Ozarkodina sagitta rhenana Superzone & 2.64 & -7.42 & Eramosa \\
\hline 48.50 & Ozarkodina sagitta rhenana Superzone & 2.61 & -6.67 & Eramosa \\
\hline 49.25 & Ozarkodina sagitta rhenana Superzone & 2.81 & -7.13 & Eramosa \\
\hline 49.50 & Ozarkodina sagitta rhenana Superzone & 2.81 & -7.13 & Eramosa \\
\hline 50.75 & Ozarkodina sagitta rhenana Superzone & 2.69 & -7.57 & Eramosa \\
\hline 52.25 & Ozarkodina sagitta rhenana Superzone & 2.67 & -7.24 & Eramosa \\
\hline 55.25 & Ozarkodina sagitta rhenana Superzone & 2.38 & -6.85 & Eramosa \\
\hline 56.25 & Ozarkodina sagitta rhenana Superzone & 2.53 & -6.55 & Eramosa \\
\hline 58.25 & Ozarkodina sagitta rhenana Superzone & 1.87 & -7.66 & Eramosa \\
\hline 61.67 & Ozarkodina sagitta rhenana Superzone & 1.94 & -7.32 & Eramosa \\
\hline 61.92 & Ozarkodina sagitta rhenana Superzone & 1.65 & -7.36 & Eramosa \\
\hline 62.83 & Ozarkodina sagitta rhenana Superzone & 1.65 & -7.38 & Eramosa \\
\hline 64.33 & Ozarkodina sagitta rhenana Superzone & 2.27 & -6.84 & Eramosa \\
\hline 64.67 & Ozarkodina sagitta rhenana Superzone & 1.51 & -7.11 & Eramosa \\
\hline 66.50 & ??? & 2.39 & -6.67 & Goat Island \\
\hline 67.67 & ??? & 2.46 & -6.92 & Goat Island \\
\hline 67.92 & ??? & 2.45 & -6.88 & Goat Island \\
\hline 69.25 & ??? & 2.82 & -6.77 & Goat Island \\
\hline 70.67 & \multicolumn{3}{|c|}{ 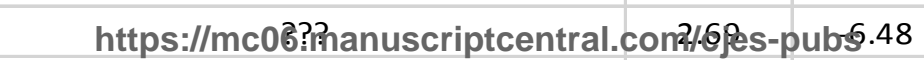 } & Goat Island \\
\hline 72.00 & ??? & 2.81 & -7.61 & Goat Island \\
\hline
\end{tabular}




\begin{tabular}{|c|c|c|c|c|}
\hline \multicolumn{5}{|c|}{ MW 07-06 Core City of Guelph, Ontario } \\
\hline Feet Down C & Conodont Zone & $\delta^{13} C_{c a r b}$ & $\delta^{18} 0$ & Formation \\
\hline 112.92 & ??? & 1.55 & -7.02 & Guelph \\
\hline 113.42 & ??? & 1.61 & -7.77 & Guelph \\
\hline 116.92 & ??? & 1.57 & -7.96 & Guelph \\
\hline 119.92 & ??? & 1.83 & -7.49 & Guelph \\
\hline 122.92 & ??? & 2.03 & -7.39 & Guelph \\
\hline 125.92 & ??? & 2.17 & -7.70 & Guelph \\
\hline 128.92 & ??? & 1.99 & -7.35 & Guelph \\
\hline 131.92 & ??? & 2.11 & -8.35 & Eramosa \\
\hline 134.92 & Kockelella ortus ortus Superzone & 2.12 & -7.75 & Eramosa \\
\hline 134.92 & Kockelella ortus ortus Superzone & 1.93 & -7.05 & Eramosa \\
\hline 136.25 & Kockelella ortus ortus Superzone & 1.94 & -7.11 & Eramosa \\
\hline 137.92 & ??? & 1.79 & -6.61 & Eramosa \\
\hline 140.92 & ??? & 1.95 & -7.22 & Eramosa \\
\hline 143.92 & ??? & 2.06 & -6.97 & Eramosa \\
\hline 144.00 & ??? & 2.15 & -7.27 & Eramosa \\
\hline 146.92 & ??? & 2.22 & -8.07 & Eramosa \\
\hline 148.00 & Lower Kockelella walliseri Zone & 2.12 & -7.04 & Eramosa \\
\hline 149.92 & Lower Kockelella walliseri Zone & 2.51 & -7.79 & Eramosa \\
\hline 152.25 & Lower Kockelella walliseri Zone & 2.42 & -7.72 & Eramosa \\
\hline 152.92 & Lower Kockelella walliseri Zone & 2.76 & -7.56 & Eramosa \\
\hline 155.92 & Lower Kockelella walliseri Zone & 3.02 & -7.78 & Eramosa \\
\hline 156.25 & Lower Kockelella walliseri Zone & 2.65 & -7.78 & Eramosa \\
\hline 158.92 & Lower Kockelella walliseri Zone & 2.79 & -7.82 & Eramosa \\
\hline 159.08 & Lower Kockelella walliseri Zone & 2.76 & -7.48 & Eramosa \\
\hline 161.92 & Lower Kockelella walliseri Zone & 1.98 & -7.44 & Eramosa \\
\hline 162.00 & Lower Kockelella walliseri Zone & 2.51 & -7.00 & Eramosa \\
\hline 164.58 & Lower Kockelella walliseri Zone & 2.98 & -7.38 & Eramosa \\
\hline 164.92 & Lower Kockelella walliseri Zone & 2.02 & -7.47 & Eramosa \\
\hline 165.92 & Lower Kockelella walliseri Zone & 2.72 & -7.46 & Eramosa \\
\hline 167.92 & Lower Kockelella walliseri Zone & 1.23 & -7.51 & Eramosa \\
\hline 168.67 & Lower Kockelella walliseri Zone & 2.35 & -7.41 & Eramosa \\
\hline 172.50 & ??? & 1.42 & -7.34 & Eramosa \\
\hline 173.92 & ??? & 1.19 & -6.61 & Eramosa \\
\hline 176.92 & ??? & 1.49 & -7.11 & Eramosa \\
\hline 179.25 & ??? & 0.88 & -6.56 & Goat Island \\
\hline 179.92 & ??? & 1.24 & -6.99 & Goat Island \\
\hline
\end{tabular}

